\title{
IHTIOFAUNA LACULUI REFRIGERENT CUCIURGAN ÎN ANUL 2020
}

\section{Mihail Mustea}

\author{
Institutul de Zoologie, e-mail: mustea91@mail.ru
}

\section{Rezumat}

Relevanța lucrării constă în faptul, că în investigațiile anterioare ale ihtiofaunei lacului refrigerent Cuciurgan, accentul principal a fost pus pe speciile economic valoroase. Cu toate acestea, o serie de specii de pești invazivi, au fost mai puțin investigați, în pofida faptului că ocupau, și ocupă în prezent, poziții dominante în structura ihtiocenozei acestui ecosistem acvatic.

Scopul lucrării constă în cercetarea și actualizarea datelor privind diversitatea, structura și starea funcțională a ihtiofaunei lacului refrigerent Cuciurgan în condiții de impact antropic și bioinvaziv sporit. A fost identificată pentru prima dată în ecosistemul lacului specia invazivă murgoiul-bălțat (Pseudorasbora parva).

Cuvinte-cheie: specii cu ciclul vital scurt, lacul refrigerent Cuciurgan, ihtiofaună, bioinvazie

\section{INTRODUCERE}

Lacul refrigerent Cuciurgan este supus unui factor antropic ridicat, ceea ce a adus la formarea caracteristicilor sale hidrochimice și creșterea excesivă a plantelor acvatice superioare. Suprafața acoperită de vegetația acvatică este de aproximativ 19\%. Dintre acumulările de apă din bazinul Nistrului, apa lacului refrigerent Cuciurgan este cea mai puternic mineralizată - $2485 \mathrm{mg} / \mathrm{l}$, care depășește norma de peste 2 ori. Motivul mineralizării ridicate este impermeabilitatea rezervorului, împreună cu termoficarea acestuia[13].

Funcționarea termocentralei a contribuit la o creștere a concentrației metalelor în apă și în sedimentele de fund, ceea ce a dus la o creștere a acumulării acestora în țesuturile plantelor, nevertebratelor și vertebratelor din rezervor, inclusiv peștii, în ale căror organe și țesuturi concentrațiile de $\mathrm{V}, \mathrm{Mo}, \mathrm{Pb}, \mathrm{Ni}, \mathrm{Cd}, \mathrm{Zn}$, $\mathrm{Cu}$ sunt semnificativ mai mari decât în pești din lacurile de acumulare Dubăssari și Kostesti, râurile Nistru și Prut. Lacul refrigerent Cuciurgan se distinge printr-o bogată diversitate de hidrobionți, inclusiv reprezentanți ai faunei Ponto-Caspice [12].

https://doi.org/10.53937/9789975151979.14

\begin{abstract}
The relevance of the paper lies in the fact that in previous investigations of the ichthyofauna of Cuciurgan cooling reservoir, the main emphasis was placed on economically valuable species. However, a number of invasive fish species have been less investigated, despite occupying, and currently occupying, dominant positions in the structure of the ichthyocenosis of this aquatic ecosystem.

The aim of the paper is to research and update data on the diversity, structure and functional status of the ichthyofauna of the Cuciurgan cooling reservoir in conditions of increased anthropogenic and bioinvasive impact. The invasive species Pseudorasbora parva was first identified in the resevoir ecosystem.
\end{abstract}

Keywords: short-lived species, Cuciurgan cooling reservoir, ichthyofauna, bioinvasion

\section{MATERIALE ȘI METODE}

Materialul ihtiologic a fost colectat în urma pescuitului științific de control din lacul refrigerent Cuciurgan în perioada martie - octombrie 2020. Pescuitul de control s-a efectuat cu plasele staționare cu lățimea laturii ochiului 20x20 mm 90x90 mm; năvod pentru puiet și volocul cu lungimea de $20 \mathrm{~m}$ și respectiv de $7 \mathrm{~m}$, având dimensiunile laturii ochiului de $12 \times 12 \mathrm{~mm}$ și respectiv de 10x10 mm. Drept unelte suplimentare neselective de pescuit, au servit: crâsnicul cu diametrul de 1,5 $\mathrm{m}$ și dimensiunile laturii ochiului $5 \times 5 \mathrm{~mm}$ și vintirele de diverse construcții.

Volumul materialului colectat constă din 3786 de indivizi, dintre care analizei gravidimensionale și de vârstă au fost supuse 275 de indivizi. Materialul ihtiologic a fost prelucrat conform metodelor standard clasice [10,11]. Determinarea speciilor de pești s-a efectuat folosind determinatoarele de specialitate $[1,5,8]$. 


\section{REZULTATE ȘI DISCUṬII}

În perioada funcționării lacului refrigerent $\mathrm{Cu}$ ciurgan s-au constatat restructurări semnificative a ihtiofaunei autohtone. Până la construcția termocentralei, ecosistemul avea o legătură naturală cu brațul Turunchuc. Ihtiofauna era reprezentată de 46 specii și subspecii de pești, aparținând la 13 familii [7], pe când, după transformarea limanului în lac de acumulare (aa.1964-1970), bogăția specifică s-a modificat în direcția reducerii diversității specifice, din cauza întreruperii migrării unor forme anadrome și potamodrome în lac după izolarea sa de brațul Turunchuc, incluzând deja 34 specii și subspecii de pești din 9 familii [6].

În același timp, ca rezultat al lucrărilor privind aclimatizarea și introducerea de noi hidrobionți din complexele faunistice a Orientului Îndepărtat și Americii de Nord în anii 1970-80, în rezervor s-a format un complex ihtiologic extrem de productiv, completat cu 8 noi specii economic valoroase: sânger, novac, cosaș, scoicar, poliodon, bester, buffalo, somn american, pelingas. Din întreaga listă a speciilor introduse, doar una s-a naturalizat - somnul american, care se reproduce în mod natural în canalele calde ale termocentralei. Populațiile altor specii de pești sunt menținute exclusiv prin reproducere artificială [4].

Până la mijlocul anilor 90, deși intensitatea termoficării lacului a început să scadă, nu s-au înregistrat modificări semnificative în structura ihtiofaunei. Astfel, ihtiofauna era reprezentată de 37 de specii de pești. În prezent ihtiofauna lacului refrigerent Cuciurgan este reprezentată de 41 specii de pești [12].

În perioada anului 2020 au fost identificate 31 specii de pești, dintre care o specie este semnalată pentru prima dată în acest ecosistem. Conform valorii dominanței speciile eudominante din lac (D5>10\%) sunt aterina-mică-pontică $(29,77 \%)$, batca comună $(20,94 \%)$ roșioara $(11,78 \%)$ și boarța comună $(10,25 \%)$, speciile dominante (D4) sunt ciobănașul $(6,71)$ și taranca/babușcă comună $(5 \%)$, alte specii - mai puțin de 5\% (Fig. 1 ).

Din punct de vedere al ponderii biomasei în capturi speciile au fost distribuite după cum urmează în fig.1: sîngerul - 19,92\%, batcă comună - 17,69\%, caras argintiu - 14,21\%, novac - 9,4\%, roșioară - 6,6\%, crap - 6,33\%, tarancă/babușcă - 5,76\%, cosaș - 5,39\%, biban - 3,59\% și știucă $2,19 \%$ alte specii - mai puțin de $2 \%$.

De menționat că în perioada anilor 1991-1995 în lac a apărut o nouă specie invazivă cu ciclu vi- tal scurt - aterina-mică-pontică, care, datorită valenței ecologice largi și potențialului reproductiv înalt, a ocupat, în scurt timp, o poziție superdominantă [12].

În rezultatul pescuitului științific de control $\mathrm{cu}$ volocul, ponderea aterinei atinge valoare de $29,77 \%$. S-a constatat că la populația locală, s-a redus de două ori, atât structura de vârstă (nu depășește doi ani), cât și ritmul de creștere.

O altă specie invazivă pentru lacul refrigerent Cuciurgan este soretele. Din anul 2004, exemplare unice de sorete au fost înregistrate în ihtiofauna lacului refrigerent Cuciurgan [12], care, cel mai probabil, a pătruns cu apa pompată din brațul Turunciuc. Din anul 2007, indivizii de sorete sunt prezenți în mod regulat în capturile de control ale lacului, efectuate de laboratorul de cercetare „Biomonitoring" [14].

Ponderea soretelui în capturile de control din lacului refrigerent Cuciurgan a crescut de la 0,5\% în 2008 pînă la 15,7\% în 2017. Din 2018, se observă o scădere a ponderii soretelui în capturile de control, care este posibil asociată cu apariția crabului olandez în ecosistemul rezervorului, care se hrănește, printre altele, $\mathrm{cu}$ icre ale acestei specii invazive. Acest lucru poate servi ca exemplu de concurență și prădătorism între două specii invazive a lacului [9]. În anul 2020 ponderea soretelui în capturile de control din lacului refrigerent Cuciurgan este de 1,58\% (Fig. 1).

Potrivit unor date [2] în Nistrul inferior și râul Prut, lungimea maximă a soretelui rareori depășește lungimea standard de $13 \mathrm{~cm}$ și o greutate de 60 g. În timp ce, în lacul refrigerent Cuciurgan, lungimea maximă a unui sorete este mai mare de $21 \mathrm{~cm}$ cu o greutate de $220 \mathrm{~g}$.

Astfel de indicatori morfologici ridicați se datorează faptului că, fiind o specie termofilă, soretele a găsit condiții favorabile în lacul refrigerent Cuciurgan, unde temperatura apei, datorită funcționării termocentralei, devine mai ridicată decât în ecosistemele naturale din regiunea noastră. Valorile gravimetrice individuale majorate sunt, de asemenea, cauzate de nutriția activă a acestei specii cu dreissenă, abundentă și înalt accesibilă în biotopul lacului [2], ceea ce denotă calitatea sa de biomeliorator.

La începutul anului 2020 a fost identificată o specie nouă pentru acest ecosistem - murgoiul-bălțat (Pseudorasbora parva). Este o specie invazivă a lacului refrigerent Cuciurgan. 

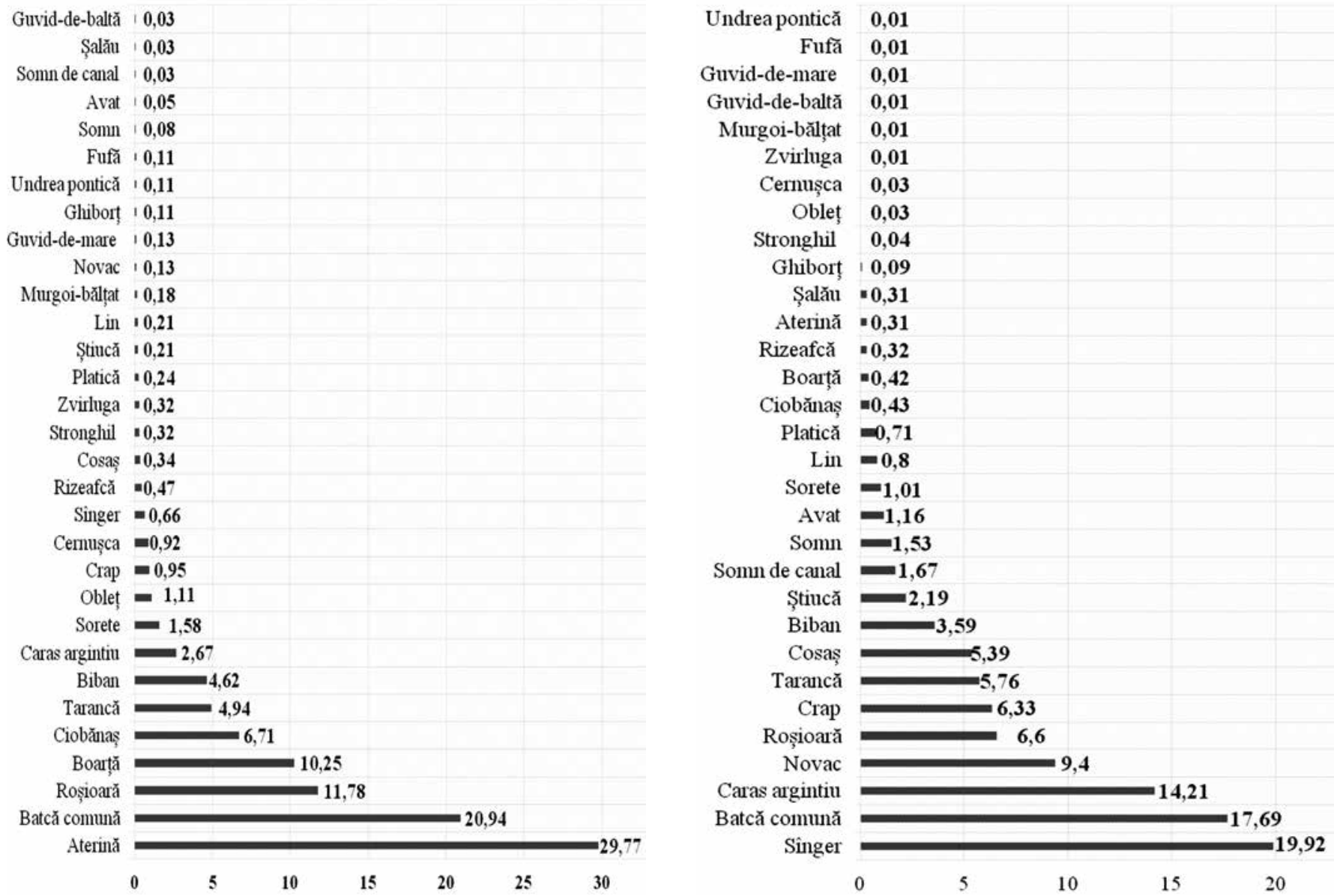

Fig. 1. Ponderea speciilor de pești în lacul refrigerent Cuciurgan și biomasa lor, anul 2020.

\section{CONCLUZII}

1. În perioada anului 2020 în ecosistemul lacului refrigerent Cuciurgan s-au identificat 31 specii de pești.

2. Speciile eudominante din lac (D5>10\%) sunt aterina-mică-pontică $(29,77 \%)$, batca comună $(20,94 \%)$ roșioara $(11,78 \%)$ și boarța comună $(10,25 \%)$.

3. A fost identificat pentru prima dată în ecosistemul lacului specia invazivă - murgoiul-bălțat (Pseudorasbora parva).

Investigațiile au fost realizate în cadrul proiectului 20.80009.7007.06 "Determinarea schimbărilor mediului acvatic, evaluarea migrației și impactului poluanților, stabilirea legităților funcționării hidrobiocenozelor și prevenirea consecințelor nefaste asupra ecosistemelor”, finanțat de Agenția Națională pentru Cercetare și Dezvoltare din Republica Moldova.

\section{BIBLIOGRAFIE}

1. Bănărescu P. 1. Pisces, Osteichthyes. (Fauna Republicii Populare Române, V.13.). București: Editura Academiei Republicii Populare Romîne, 1964. 935 p.

2. Bulat Dumitru. Ihtiofauna Republicii Moldova: amenintări, tendinte si recomandări de reabilitare // Monografie. Chișinău, 2017. P. 343.

3. Kottelat M., Freyhof J. Handbook of European freshwater fishes. Berlin, 2007. 646 p.

4. Usatîi A., Crepis O., Șaptefrați N., Strugulea O., Cebanu A. Particularitățile acțiunilor complexe a factorilor antropogeni asupra schimbărilor structurii ihtiofaunei și populațiilor de pești în lacurilor bazinului fl. Nistru // Academician Leo Berg - 135: Collection of Scientific Articles. - Bendery, 2011. - 176-181.

5. Берг Л.С. Рыбы пресных вод СССР и сопредельных стран // Определители по фауне СССР. М.-Л.: АН СССР, 1948 - 1949. - T. 1 - 3. - 1382 c.

6. Владимиров М.3. Распределение и динамика численности рыб // Кучурганский лиман-охладитель Молдавской ГРЭС. - Кишинев, 1973. c.119-125. 
7. Замбриборщ Ф.С. Ихтиофауна лиманов северо-западного Причерноморья. Тр. I ихтиологической конференции по изучению морских лиманов северо-западной части Черного моря. Киев: Науч. Думка, 1960. С. 95-103.

8. Мошу А., Тромбицкий И. Рыбы среднего и нижнего Днестра. Справочник хранителей реки. Кишинэу, 2013. 139 с.

9. Мустя M.B. Солнечный окунь (Lepomis gibbosus) Кучурганского водохранилища $u$ его первая находка в Дубоссарском водохранилище // EU integration and management of the Dniester river basin”, October 8-9, 2020. Chisinau, Moldova.

10. Никольский Г.В. Частная ихтиология. М.: Высшая школа. 1971.

11. Правдин И.Ф. Руководство по изучению рыб (преимущественно пресноводных). Москва: Пищевая промышленность, 1966. 376 c.

12. Стругуля О.В., Мустя М.В. Изменение ихтиоценоза Кучурганского водохранилища в историческом плане и современное состояние их- тиофауны водоема // Hydropower impact on river ecosystem functioning: Proceedings of the International Conference, Tiraspol, Moldova, October 8-9, 2019 Tiraspol: Eco-Tiras, 2019 (Tipogr. «Print-Caro»). - C 319-326.

13. Филипенко С.И., Зубкова Н.Н., Тихоненкова Л.А., Филипенко Е.Н. Промысловая ихтиофауна Кучурганского водохранилища и роль отдельных видов в накоплении металлов в водоеме-охладителе Молдавской ГРЭС // International symposium «Functional ecology of animals»: dedicated to the 70th anniversary from the birth of academician Ion Toderaş, 21 september 2018. - Chişinău: Imprint Plus, 2018. - C. 413-420.

14. Филипенко С.И., Митрохин И.Г. Современное состояние ихтиофауны Кучурганского водохранилища // Чтения памяти кандидата биологических наук, доцента Л.Л. Попа. - Тирасполь: Изд-во Приднестр. ун-та, 2010. - С. 67-78. 